УДК 339.1:330.341.1:658

DOI: https://doi.org/10.37320/2415-3583/11.24

Кащена Н.Б.

кандидат економічних наук, доцент, Харківський державний університет харчування та торгівлі ORCID: https://orcid.org/0000-0001-7069-8860

\title{
ФОРМУВАННЯ ІННОВАЦІЙНОЇ СТРАТЕГІЇ УПРАВЛІННЯ ЕКОНОМІЧНОЮ АКТИВНІСТЮ ПІДПРИЕМСТВА ТОРГІВЛІ
}

У статті розглянуто теоретико-методичні засади формування інновачійних стратегій управління економічною активністю підприємств торгівлі. Доведено, щуо інновачійна стратегія економічної активності торговельних підприємств є стратегією розвитку, орієнтованою на використання інновачій для формування конкурентних переваг високого порядку, підвищення ринкової активності та вартості підприємства в умовах швидкоплинних змін бізнес-середовища та потреб стейкхолдерів. Визначено принцини та розроблено алгоритмічну модель формування й реалізації інноваційної стратегї розвитку економічної активності підприємств торгівлі, яка втілює ключові процеси стратегування (мислення, планування, управління, реалізація, аналіз ситуаџї̈ та наслідків дій) $i$ дає змогу структурувати порядок дій із розроблення, втілення, контролю виконання та корегування стратегії.

Ключові слова: підприємство торгівлі, економічна активність, інновації, розвиток, інноваційна стратегія.

Постановка проблеми. За насиченості ринку та ринкової турбулентності, що посилюється й прогресує за ступенем розвитку глобалізаційних процесів, запорукою підвищення економічної активності суб'єктів торговельної діяльності $€$ ефективне їх функціонування на засадах інноваційності та клієнтоорієнтованості. Інновації, спрямовані на покращення рівня обслуговування споживачів, комунікації з клієнтами та посилення конкурентних переваг, поновлюють ділову репутацію підприємств торгівлі та змінюють пропозицію послуг на ринку. Розширення й оновлення наявного функціоналу торговельної діяльності пов' язані з формуванням якісно нових організаційних, технологічних і людських можливостей підприємств ритейлу. Дедалі більшої актуальності в цьому контексті набуває спрямований пошук адекватних сучасним викликам новітніх інструментів бізнес-управління, орієнтованих на задоволення ціннісних очікувань споживачів, підвищення економічної активності та інноваційний розвиток торговельних підприємств. Отже, пріоритетним є дослідження теоретико-методичних засад формування інноваційних стратегій управління економічною активністю підприємств торгівлі.

Аналіз останніх досліджень i публікацій. Проблемні аспекти теорії та практики формування інноваційних стратегій підприємств $€$ предметом пильної уваги сучасних вітчизняних і зарубіжних науковців. Актуальні питання інноваційної спрямованості розвитку підприємств роздрібної торгівлі, формування відповідних стратегій та визначення перспектив розглядали у своїх працях А.М. Безус [1], I.О. Бучацька [6], Ю.С. Валеєва [2], С.А. Давимука [8], Л.К. Кавтарадзе [9], Л.О. Лігоненко [15], К.Й. Пугачевська [18], Л.І. Федулова [22], М.Б. Шевчун [1] та інші вчені. Проте через різноплановість інновацій, перенасиченість ринку та зростаючі потреби споживачів багато питань, що стосуються сутності інноваційної стратегії та технології її формування з позиції активізації економічної діяльності торговельних підприємств, залишаються дискусійними та потребують подальшого розвитку.

Мета статті полягає в обгрунтуванні теоретико-методичних засад формування стратегії управління економічною активністю підприємств торгівлі на інноваційних засадах.

Виклад основного матеріалу. Під економічною активністю торговельних підприємств слід розуміти досягнення бажаного рівня ефективності та результативності функціонування в умовах динамічних змін бізнес-середовища та потреб стейкхолдерів, інтенсивність його змін у часі й просторі та власне еволюцію на засадах інноваційності, адаптації та емерджентності [12, с. 118].

Ефективність управління економічною активністю визначається відповідно вибраною стратегією. Специфічні умови господарювання торговельних підприємств, що ускладняються під впливом безлічі внутрішніх та зовнішніх факторів, визначають необхідність розроблення інноваційних стратегій, орієнтованих на стабілізацію та зростання економічної активності, які враховують платоспроможний попит та швидкозростаючі потреби споживачів, наявний потенціал конкурентоспроможності, можливість гнучкої адаптації до змін бізнес-оточення й потреб стейкхолдерів, а також передбачають активне залучення торговотехнологічних інновацій.

Слід зазначити, що в торгівлі інновації здебільшого пов'язані 3 появою нової чи вдосконаленням наявної послуги або технології іiі надання. Нині значного поширення в практиці сучасних 
підприємств ритейлу набули такі торгові інновації, як вендинг (торгівля через автомати) (наприклад, автомати з продажу кави, газованих напоїв, снеків, води); зміна формату магазину (гіпермаркет «нового покоління», об'єднання дискаунтера та «магазину біля дому», віртуальний магазин, тематичні формати стилю (анімаційні, морські, еко- тощо)); новітні формати цільової аудиторії (зокрема, еліт-сегменту (елітний гастрономічний магазин, елітні винні магазини) та екологічної торгівлі (еко-крамниці), супермаркети для представників середнього класу, м'який дискаунтер або соціальний магазин для малозабезпечених верств населення); спеціальні пропозиції («акційні товари на обмежений період часу», «купуй та обмінюй», сервіс «здійснення спільних покупок»); удосконалення використання торговельного обладнання (комбінація звичайних полиць 3 висувними); запровадження власних торгових марок з орієнтацією на різних споживачів; ритейл на автозаправних станціях; мобільна комерція; екологізація торгівлі.

Для прискорення товароруху, покращення результативності використання фінансово-економічних ресурсів та підвищення якості обслуговування споживачів, а також створення умов для зростання продуктивності праці, зниження витрат i підвищення ефективності господарювання загалом торговельні підприємства активно застосовують новітні технології управління окремими бізнеспроцесами, зокрема штрихкодування, радіочастотну ідентифікацію (RFID), комунікацію ближнього поля (NFC), термінали самообслуговування, електронні цінники, надолонні каси, автоматичний роботизований склад, мобільні та інтернет-технології просування товарів (концепція SoLoMo).

Різноманіття торгово-технологічних інновацій спонукає менеджмент підприємств торгівлі розробляти відповідні інноваційні стратегії економічної активності. Формування та вибір інноваційної стратегії $\epsilon$ найголовнішим компонентом циклу стратегічного управління економічною активністю торговельного підприємства, отже, потребує наукового обгрунтування теоретичного базису та алгоритмізації дій 3 iї розроблення та реалізації.

Компаративний аналіз сучасної термінології та основних положень стратегічного управління активністю економічних систем із залученням інновацій виявив, що інноваційні стратегії ідентифікуються на рівні підприємства, галузі, регіону, держави. Щодо підприємства інноваційна стратегія ідентифікується як елемент системи стратегічного управління й трактується так:

- генеральна лінія поведінки (надстратегія) підприємства, орієнтована на використання інновацій задля економічного зростання, задоволення потреб стейкхолдерів і вирішення проблемних ситуацій негативного характеру під час управління змінами [13, с. 90];

- складова частина загальної стратегії підприємства, орієнтована на визначення та досягнення перспективних цілей безпосередньо через інноваційний процес [3, с. 215; 19, с. 97];

- комплексний довгостроковий план дій, орієнтований на досягнення довгострокових цілей підприємства, що конкретизує місію, цілі та шляхи ïх досягнення на різних етапах життєвого циклу підприємства, сформований з урахуванням його інноваційно-інвестиційного потенціалу та підлягає постійному корегуванню через динамічність змін бізнес-оточення $[5$, с. $165 ; 8$, с. $241 ; 20$, с. 377 ; 21, c. 105];

- будь-який засіб досягнення цілей підприємства, відмінністю якого $є$ його новітність насамперед для підприємства, а також споживачів, ринку й країни загалом [1, с. 136];

- комплекс інноваційних заходів, орієнтованих на впровадження різних нововведень задля досягнення цільових параметрів економічного зростання $[4$, с. 105$]$;

- взаємопов'язана сукупність дій, що забезпечують високу ефективність інновацій, спрямованих на успішне виконання місії підприємства, досягнення його довгострокових цілей (ефективне використання інноваційного потенціалу, оптимізація бізнес-процесів, зміцнення життєздатності, підвищення конкурентоспроможності тощо) 3 урахуванням ендогенних та екзогенних факторів бізнес-середовища [23, с. 85];

- стратегія, орієнтована на передбачення змін бізнес-середовища, генерування змін усередині підприємства та акумулювання ефективних управлінськихрішеньщодонихзпозиціїформуванняконкурентних переваг за рахунок інновацій [16, с. 85];

- механізм розподілу ресурсів підприємства, спрямований на досягнення конкурентних переваг у довгостроковій перспективі за рахунок ефективного здійснення інноваційної діяльності [7, с. 47];

- система довгострокових концептуальних установок розподілу ресурсів між траєкторіями інноваційного розвитку системи, а також їхнього перерозподілузазміни внутрішніх ізовнішніх умов iii функціонування, що включає науково-технічний, організаційний, мотиваційний і матеріальнофінансовий механізми забезпечення [17, с. 49].

Репрезентована в економічній літературі варіативність наукової думки про сутність інноваційної стратегії підприємства свідчить про те, що вона $\epsilon$ знаряддям переведення підприємства до цільового стану, який визначають такі характеристики, як орієнтованість на довгострокові перспективи; інноваційний шлях досягнення цільових параметрів результативності господарювання та розвитку; впровадження різних інновацій та нововведень (економічних, технологічний, управлінських 
тощо); передбачення та гнучке реагування на швидкоплинні зміни бізнес-середовища й потреб стейкхолдерів; спрямованість управлінської діяльності на розроблення ефективної моделі стратегічної поведінки підприємства на ринку; планування дій і формування пакету заходів із забезпечення конкурентних переваг та розвитку підприємства; атрибут досягнення стратегічної конкурентної переваги. Саме вони посилюють поліаспектність інноваційних стратегій та обумовлюють відмінність наявних підходів від інтерпретації їх сутності та типології.

Грунтуючись на вищевикладеному, під інноваційною стратегією управління економічною активністю підприємств торгівлі пропонуємо розуміти стратегію розвитку, орієнтовану на використання інновацій для формування конкурентних переваг високого порядку, підвищення ринкової активності та вартості підприємства в умовах швидкоплинних змін бізнес-середовища та потреб стейкхолдерів. Як композиційний елемент процесу стратегічного управління $[11$, с. 128$]$ вона визначає інноваційний імператив дій суб'єктів управління, спрямованих на визначення, забезпечення та успішну реалізацію місії, візії та цілей підприємства. Фактично інноваційна стратегія торговельного підприємства відображає логіку, якою керуються суб'єкти різних рівнів управління, принципи, яких вони дотримуються, методи та конкретні інноваційні засоби, які вибираються ними для досягнення поставлених цілей, а також потрібні для цього ресурси. Внаслідок впливу швидкоплинних змін факторів бізнессередовища та потреб стейкхолдерів (банки, конкуренти, контрагенти, споживачі тощо) вибрана інноваційна стратегія піддається постійному уточненню та корегуванню.

Формування, вибір і реалізація інноваційної стратегії управління економічною активністю підприємства торгівлі підпорядковуються певним принципам (зокрема, визнання пріоритетності моделі інноваційного розвитку; чітка ідентифікація внутрішніх можливостей та зовнішніх загроз для розвитку; перманентний моніторинг споживчого ринку; адекватність фінансоворесурсного потенціалу; цілеспрямованість, комплексність, планомірність; клієнтоорієнтованість та високий рівень адаптивності; мотивація персоналу до якісного розроблення та ефективності стратегічних змін), а визначаються логічною послідовністю етапів процесу розроблення та реалізації стратегії. Задля забезпечення його ефективності розроблено та запропоновано до впровадження алгоритмічну модель формування й реалізації інноваційної стратегії розвитку економічної активності підприємств торгівлі (рис. 1).

Теоретико-методичний базис представленої моделі склали результати попередніх наукових досліджень стратегічного планування $[11$, с. 130 ; 12, с. 118], комплексний та системний підходи. Запропонована модель структурує порядок дій iз розроблення, втілення, контролю виконання та корегування інноваційної стратегії розвитку економічної активності торговельного підприємства в умовах змін бізнес-середовища та потреб стейкхолдерів від визначення стратегічних орієнтирів, потенційних можливостей та загроз іiі реалізації. Логіко-смислова структура моделі відображає ключові процеси стратегування (мислення, планування, управління, реалізація, аналіз ситуації та наслідків дій) і охоплює п’ять таких етапів:

- стратегічний аналіз і діагностика бізнессередовища (орієнтований на якісний моніторинг внутрішнього й зовнішнього бізнес-середовища, діагностику ефективності ресурсного забезпечення та визначення інноваційних драйверів вирішення наявних проблем);

- формування концепції економічної активності торговельного підприємства на інноваційних засадах (передбачає створення теоретикометодологічної платформи для імплементації інноваційних імперативів розвитку та їх інтеграціï із загальною стратегією розвитку підприємства в довгостроковій перспективі);

- аналіз стратегічних альтернатив і вибір адекватної змінам бізнес-середовища інноваційної стратегії, що враховує баланс інтересів стейкхолдерів (спрямований на ідентифікацію та узгодження цілей, інноваційних компонентів та ресурсного забезпечення досягнення цільових параметрів розвитку економічної активності підприємства торгівлі, розроблення стратегічних альтернатив, вибір найбільш адекватної викликам бізнессередовища та змінам уподобань споживачів інноваційної стратегіï та бізнес-моделі іiі реалізації);

- реалізація інноваційної стратегії економічної активності та розвитку торговельного підприємства (визначає порядок проведення стратегічних змін у межах бюджетних ресурсів на підставі попередньо розробленого плану переходу економічної активності з поточного до цільового рівня);

- контроль за реалізацією інноваційної стратегії розвитку економічної активності (забезпечує якісний моніторинг виконання стратегічних планів та програм, контроль втілення стратегічних змін та оцінювання їх ефективності, а через необхідність забезпечення балансу власних інтересів і потреб стейкхолдерів в умовах динамічних змін бізнессередовища - внесення відповідних корегувань та регламентацію заходів із покращення стратегічних альтернатив i технології їх реалізації).

Використання запропонованої моделі в управлінській практиці дасть змогу моделювати інноваційні стратегії розвитку економічної активності торговельного підприємства, формувати множину їх варіантів та вибирати найбільш адекватні 


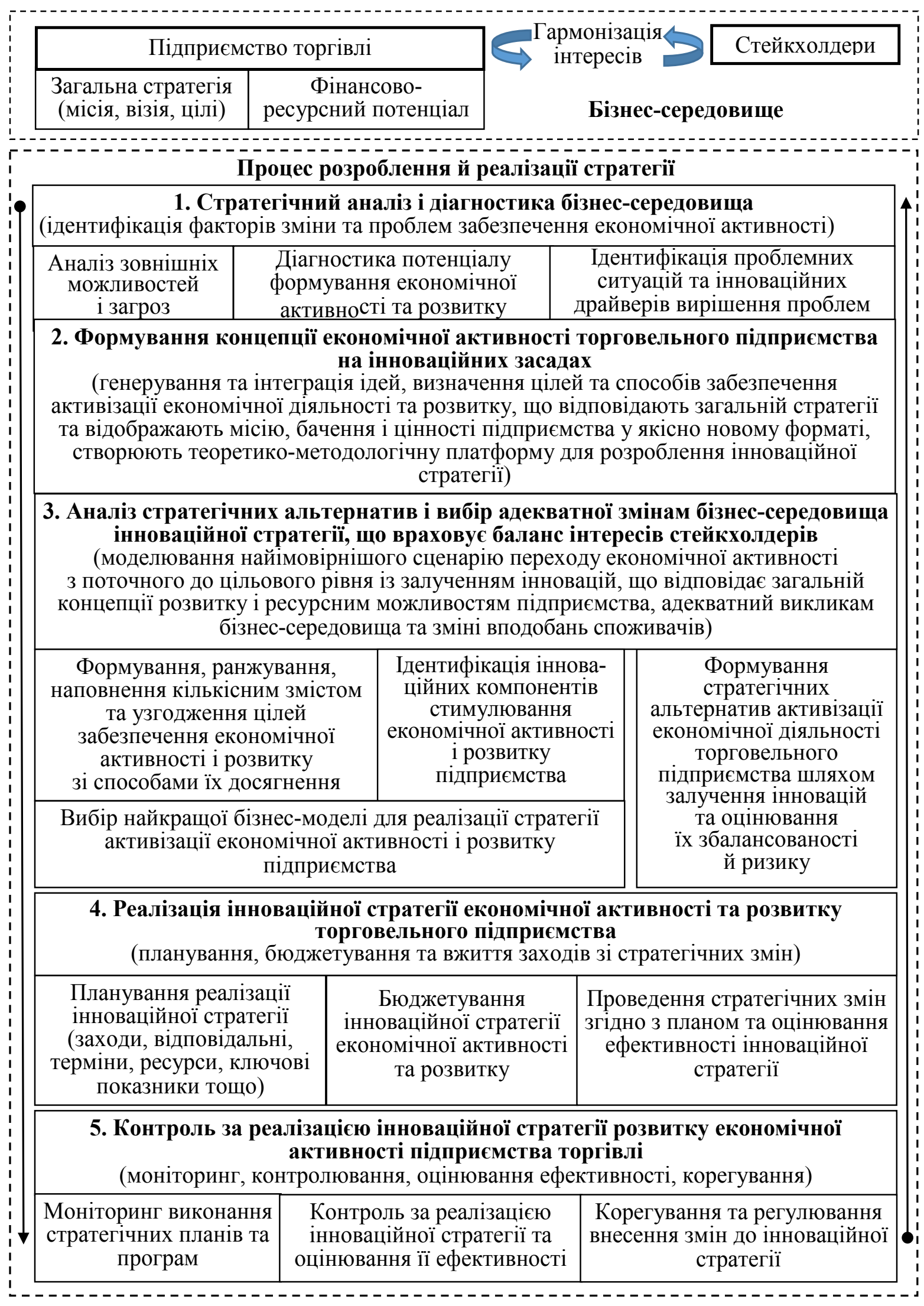

Рисунок 1 - Алгоритмічна модель формування й реалізації інноваційної стратегії розвитку економічної активності підприємств торгівлі 
сучасним змінам бізнес-середовища та потреб стейкхолдерів, що сприятиме підвищенню ефективності стратегічного управління в системі забезпечення активізації економічної діяльності підприємств ритейлу.

Висновки. Дослідження теоретико-методичних засад формування стратегії управління економічною активністю підприємств торгівлі на інноваційних засадах виявило, що наявність інноваційної стратегї розвитку економічної активності $є$ запорукою ефективності функціонування та економічного зростання підприємств торгівлі в конкурентному середовищі. Доведено, що іiі особливістю є імператив інновацій і нововведень під час формування суб'єктами різних рівнів управління логіки (якою вони керуються), принципів (яких вони дотримуються), методів та конкретних засобів (які ними вибираються) досягнення цільо- вих параметрів розвитку економічної активності торговельного підприємства. Безпосередньо формування інноваційної стратегії - це системний процес, що базується на відповідній методології та передбачає оцінювання умов, у яких працює підприємство, визначення його місії, стратегічних інноваційних цілей та завдань активізації економічної діяльності, виявлення основних напрямів та превентивних інноваційних заходів за максимального використання всіх можливих ресурсів. Рушійною силою втілення стратегічних задумів $\epsilon$ відповідний функціональний механізм, тому перспективи подальших наукових пошуків визначаються потребою розбудови механізму управління економічною активністю підприємств ритейлу, здатного забезпечити досягнення цільових параметрів їі розвитку в умовах динамічних змін бізнес-середовища та потреб стейкхолдерів.

\section{Список використаних джерел:}

1. Безус А.М., Шевчун М.Б., Безус П.І. Перспективи інноваційного розвитку роздрібної торгівлі в Україні. Економіка та держава. 2019. № 5. С. 24-28.

2. Валеева Ю.С. Сущность и классификация инноваций торговых сетей. Вестник Академии. 2015. № 3. С. 37-40.

3. Вергал К.Ю. Теоретичні підходи до класифікації інноваційних стратегій. Теоретичні і практичні аспекти економіки та інтелектуальної власності. 2011. Вип. 2. С. 214-219.

4. Горохова А.Е. Совершенствование процесса стратегического управления промышленным предприятием. Модернизаџия. Инноващии. Развитие. 2015. Т. 6. № 2. С. 102-107.

5. Гриньов А.В. Інноваційний розвиток промислових підприємств: концепція, методологія, стратегічне управління. Харків : ІНЖЕК, 2003. 308 с.

6. Дубовик Т.В., Бучацька І.О. Інноваційна спрямованість розвитку підприємств роздрібної торгівлі. Маркетинг $i$ менеджмент інновацій. 2017. № 1. С. 223-230.

7. Егоркин С.С. Формирование инновационной стратегии развития предприятий пищевой промышленности. Becmник Красноярского государственного аграрного университета. 2011. Вып. 2. С. 47-52.

8. Інноваційний розвиток підприємств сфери торгівлі: світові тенденції та практика в Україні : монографія / за заг. ред. С.А. Давимуки. Львів : ДУ «Інститут регіональних досліджень імені М.І. Долішнього НАН України», 2016.432 с.

9. Кавтарадзе Л.К. Инновации в современной розничной торговле. Риск. 2015. № 3. С. 171-173.

10. Калінеску Т.В., Пономарьова І.В., Наталенко М.О. Інноваційна стратегія розвитку підприємств на основі збалансованої системи показників : монографія. Луганськ : вид-во СНУ ім. В. Даля, 2013. 286 с.

11. Кащена Н.Б. Моделювання процесу стратегічного управління економічною активністю торговельного підприємства. Інфраструктура ринку. 2019. Вип. 34. С. 125-134. DOI: https://doi.org/10.32843/infrastruct34-18.

12. Кащена Н.Б. Теоретичні аспекти економічної активності підприємств торгівлі. Вісник Одеського національного університету. Серія: Економіка. 2018. Т. 23. Вип. 7. С. 115-121.

13. Ковтун О.І. Імператив інноваційної стратегії в системі управління конкурентоспроможністю для вітчизняних підприємств в умовах перманентної кризи національної економіки. Вісник Сумського державного університету. Серія: Економіка. 2013. № 1. С. 86-101.

14. Кулаєць М.М., Куцеконь Л.О. Стратегія інноваційного розвитку сільськогосподарських підприємств. Економіка АПК. 2009. № 7. С. 75-80.

15. Лігоненко Л.О. Інноваційний вектор розвитку торгівлі в Україні. Товары и рынки. 2011. № 1. С. 7-14.

16. П'ятницька Г.І. Інноваційні стратегії в сучасних умовах господарювання: суть та наукові підходи до формування вибору. Проблеми науки. 2011. № 11. С. 21-29.

17. Подрєза С.М., Кам'янецька О.В. Особливості та проблеми побудови інноваційної стратегії в системі стратегічного розвитку підприємства. Формування ринкових відносин в Україні. 2006. № 7. С. 48-52.

18. Пугачевська К.Й. Стратегічні напрями і тенденції інноваційного розвитку торгівлі. Науковий вісник Міжнародного гуманітарного університету. Серія: Економіка іменеджмент. 2015. Вип. 12. С. 58-60.

19. Рогоза М.Є., Вергал К.Ю. Стратегічний інноваційний розвиток підприємств: моделі та механізми : монографія. Полтава : РВВ ПУЕТ, 2011. 136 с.

20. Семенюк О.М. Узагальнення теоретичних підходів до сутності інноваційної стратегії підприємства. Економічний аналіз. 2013. Т. 13. С. 372-379.

21. Сиротинська Н.М. Стратегічне планування інноваційної діяльності машинобудівних підприємств. БізнесІнформ. 2014. № 9. С. 103-108.

22. Федулова Л.І. Інноваційність розвитку сфери торгівлі. Вісник Київського національного торговельно-економічного університету. 2016. № 3. С. 17-33.

23. Юринець 3.В. Формування інноваційних стратегій: теорія, методологія, практика : монографія. Львів : СПОЛОМ, 2016. 412 c. 


\section{References:}

1. Bezus A.M., Shevchun M.B., Bezus P.I. (2019) Perspekty'vy' innovacijnogo rozvy'tku rozdribnoyi torgivli v Ukrayini [Prospects for innovative retail development in Ukraine]. Ekonomika ta derzhava, vol. 5, pp. 24-28.

2. Valeeva Yu.S. (2015) Sushhnost' y' klassy'fy'kacy’ya y'nnovacy'j torgovыx setej [Essence and Classification of Innovation of Retail Networks]. Vestnik Akademii, vol. 3, pp. 37-40.

3. Vergal K.Y. (2011) Teorety'chni pidxody' do klasy'fikaciyi innovacijny'x strategij [The theoretical approaches to the classification of innovative strategies]. Theoretical and practical aspects of economics and intellectual property, vol. 2, pp. 214-219.

4. Gorokhova A.E. (2015) Sovershenstvovany'e processa strategy'cheskogo upravleny’ya promyshlennym predpry'yaty'em [Improvement of strategic management of the industrial enterprise]. Modernization. Innovation. Research, vol. 6 , no. 2 , pp. $102-107$.

5. Hrynov A.V. (2003) Innovatsiinyi rozvytok promyslovykh pidpryiemstv: kontseptsiia, metodolohiia, stratehichne upravlinnia [Innovative development of industrial enterprises: concept, methodology, strategic management]. Harkiv : INZhEK.

6. Dubovik T.V., Buchatska I.O. (2017) Innovacijna spryamovanist' rozvy'tku pidpry'yemstv rozdribnoyi torgivli [Innovative orientation of development of retail trade enterprises]. Marketing and innovation management, no. 2, pp. $223-230$.

7. Ehorkyn S.S. (2011) Formyrovanye ynnovatsyonnoi stratehyy razvytyia predpryiatyi pyshchevoi promyshlennosty [Formation of innovative development strategies of the food industry]. Bulletin of the Krasnoyarsk State Agricultural University, no. 2, 47-52.

8. Davimuka S.A. (Eds.). (2016) Innovacijny’j rozvy’tok pidpry’yemstv sfery’ torgivli: svitovi tendenciyi ta prakty'ka v Ukrayini : monografiya [Innovative development of trade enterprises: world trends and practice in Ukraine: monograph]. Lviv : State institution "Institute of Regional Researchnamed after M.I. Dolishniy of the NAS of Ukraine".

9. Kavtaradze L.K. (2015) Y'nnovacy'y' v sovremennoj rozny'chnoj torgovle [Innovations in modern retail]. Risk, vol. 3, pp. 171-173.

10. Kalinescu T.V., Ponomareva I.V., Natalenko M.O. (2013) Innovacijna strategiya rozvy'tku pidpry’yemstv na osnovi zbalansovanoyi sy'stemy' pokazny'kiv : monografiya [Innovative strategy of enterprise development based on a balanced scorecard : a monograph]. Luhansk : Volodymyr Dahl East Ukrainian National University.

11. Kashchena N.B. (2019) Modelyuvannya procesu strategichnogo upravlinnya ekonomichnoyu akty'vnistyu torgovel'nogo pidpry'yemstva [Modelling of the process of strategic management of economic activity of a trading enterprise]. Market Infrastructure, vol. 34, pp. 125-134. DOI: https://doi.org/10.32843/infrastruct34-18.

12. Kashchena N.B. (2018) Teorety'chni aspekty' ekonomichnoyi akty'vnosti pidpry'yemstv torgivli [Theoretical aspects of economic activity of trade enterprises[. Odessa National University. Economy, p. 23, vol. 7, pp. 115-121.

13. Kovtun O.I. (2013) Imperaty’v innovacijnoyi strategiyi v sy’stemi upravlinnya konkurentospromozhnistyu dlya vitchy'znyany'x pidpry'yemstv v umovax permanentnoyi kry'zy' nacional'noyi ekonomiky' [Imperative of innovative strategy in control system by a competitiveness for domestic enterprises in the conditions of permanent crisis of national economy]. Bulletin of Sumy State University. Series: Economics, no. 1, pp. 86-101.

14. Kulaiets M.M.. Kutsekon L.O. (2009). Stratehiia innovatsiinoho rozvytku silskohospodarskykh pidpryiemstv [The strategy of innovative development of farms]. Ekonomika APK, no. 7, pp. 75-80.

15. Lyhonenko L.O., Krasnenevich G.L. (2011) Innovacijny'j vektor rozvy'tku torgivli v Ukrayin [Innovative vector of trade development in Ukraine]. Commodities and Markets, vol. 1, pp. 7-14.

16. Pyatnytska G.I. (2011) Innovacijni strategiyi v suchasny’x umovax gospodaryuvannya: sut' ta naukovi pidxody' do formuvannya vy'boru [Innovative strategies in modern business conditions: the essence and scientific approaches to the formation of choice]. Problems of science, no. 11, pp. 21-29.

17. Podreza S.M., Kamyanetskaya O.V. (2006) Osobly’vosti ta problemy' pobudovy' innovacijnoyi strategiyi v sy'stemi strategichnogo rozvy'tku pidpry'yemstva [Features and problems of construction of innovation strategy in the system of strategic development of the enterprise]. Formation of market relations in Ukraine, no. 7, pp. 48-52.

18. Pugachevskaya K.Y. (2015) Strategichni napryamy' i tendenciyi innovacijnogo rozvy'tku torgivli [Strategic directions and tendencies of innovative trade development]. Scientific Bulletin of the International Humanities University. Series: Economics and Management, vol. 12, pp. 58-60.

19. Rohoza M.Ie., Verhal K.Yu. Stratehichnyi innovatsiinyi rozvytok pidpryiemstv: modeli ta mekhanizmy : monografiya [Strategic development of innovative enterprises: models and mechanisms : monograph]. Poltava : RVV PUET.

20. Semenyuk O.M. (2013) Uzagal'nennya teorety'chny'x pidxodiv do sutnosti innovacijnoyi strategiyi pidpry'yemstva [Theoretical approaches generalisation to the nature of an enterprise innovative strategy]. Ekonomichnyy analiz, p. 13, pp. 372-379.

21. Syrotynska N.M. Strategichne planuvannya innovacijnoyi diyal'nosti mashy'nobudivny'x pidpry'yemstv [Strategic Planning of the Innovation Activity in the Machine-Building Enterprises]. Business-Inform, no. 9, pp. 103-108.

22. Fedulova L.I. (2016) Innovacijnist' rozvy'tku sfery' torgivli [Innovative development of trade]. Bulletin of Kyiv National University of Trade and Economics, no. 3. pp. 17-33.

23. Yurinets Z.V. (2016) Formuvannya innovacijny’x strategij: teoriya, metodologiya, prakty'ka : monografiya [Formation of innovative strategies: theory, methodology, practice : monograph]. Lviv : SPOLOM. 
Kashchena Nataliia

Kharkiv State University of Food Technology and Trade

\section{FORMATION OF INNOVATIVE STRATEGY OF MANAGEMENT OF ECONOMIC ACTIVITY OF TRADE ENTERPRISE}

Changing market conditions, a high degree of business uncertainty and the latest retail trends determine the need to develop strategies aimed at increasing the economic activity of trade enterprises, based on the active involvement of trade and technological innovations. The purpose of the article is to substantiate the theoretical and methodological principles of forming a strategy for managing the economic activity of trade enterprises on an innovative basis. The study was conducted on the basis of a systematic approach to knowledge of methodological aspects of strategic management of economic activity of trade enterprises using general and special principles and methods (scientific abstraction, comparative analysis, generalization, and logical, monographic, specification, graphic). The innovative strategy of economic activity of trade enterprises is defined as a development strategy focused on the use of innovations to form high-order competitive advantages, increase market activity and enterprise value in the face of rapid changes in the business environment and needs of stakeholders. The principles of formation of innovative strategy of economic activity of the trade enterprise are defined and the corresponding algorithmic model defining sequence of its development and realization is developed. The logical-semantic structure of the proposed model reflects the key processes of strategy (thinking, planning, and management, and implementation, analysis of the situation and the consequences of actions) and includes five stages that structure the process of developing, implementing, monitoring and adjusting strategy. The use of the proposed model in management practice will allow to model, form a set of options and choose the most appropriate to modern changes in the business environment and the needs of stakeholders' innovative strategies for the development of economic activity of the trading company. A promising area of further research is the development of a mechanism for managing the economic activity of retail enterprises, able to ensure the achievement of target parameters of its development.

Key words: trade enterprise, economic activity, innovations, development, innovation strategy.

JEL classification: L17, L26, M21. 